\title{
Działania z obszaru konserwacji zapobiegawczej: audyt konserwatorski - metoda i przykłady
}

\section{Wprowadzenie}

W niu dziedzictwa kulturowego podlegającego ochronie - np. różnorodnych zbiorów i kolekcji muzealnych, archiwalnych, bibliotecznych, stanowisk archeologicznych i innych - powinny, w celu ich optymalizacji, zostać poprzedzone operacjami, które pozwola na określenie rzeczywistych potrzeb i wskazanie właściwych i odpowiadających konkretnym potrzebom dróg ich zaspokojenia.

Zgodnie z procedurami konserwacji zapobiegawczej wypracowywanymi już od lat 90. XX wieku, w najpełniejszym wymiarze zawiera je tzw. audyt konserwatorski. W niniejszym tekście przedstawiony zostanie on w wersji wypracowanej we Francji, gdzie od 1994 roku nauczany jest w toku studiów Konserwacji Zapobiegawczej Dziedzictwa ${ }^{1}$.

1 Studia podyplomowe Master professionnel de Conservation préventive du Patrimoine, na Université Paris I Panthéon-Sorbonne, zaadresowane do przedstawicieli różnych zawodów pracujących na rzecz dziedzictwa kulturowego (kuratorów, kustoszy, dokumentalistów, kon- 


\section{Audyt konserwatorski - definicja i cel}

Formuła działań określonych tym mianem wypracowana została w toku ostatnich dwudziestu lat, bazując na anglosaskich dokonaniach w tym zakresie, w twórczy sposób rozwiniętych ${ }^{2}$. Audyt konserwatorski oznacza ewaluację, czyli wartościująca ocenę zarządzania zbiorami, pojmowanego jako stwarzanie warunków właściwej ich eksploatacji oraz działania służące ich zachowaniu. Jego celem jest przedstawienie kompletnego i globalnego obrazu zbiorów w danej instytucji, zidentyfikowanie istniejących problemów konserwatorskich (w rozumieniu szerokim, tj. dotyczących wszelkich okoliczności warunkujących zachowanie zbiorów) i doprowadzenie do zmiany - poprawy sytuacji w dążeniu do sytuacji wzorcowej. Rezultatem - korzyścia dla danej instytucji sprawującej opiekę nad zbiorami - jest uzyskanie świadomości rzeczywistej sytuacji, ukazanej jako system powiązanych ze soba składowych, poznanie zarówno jej słabych, jak i mocnych stron i uzyskanie narzędzi pozwalających na poprawę tych jej elementów, które wymagaja korekty czy regulacji. Przeprowadzenie audytu konserwatorskie-

serwatorów-restauratorów, architektów, architektów-muzeografów). Program tego kształcenia powstał we współpracy Dyrekcji Muzeów Francuskich (DMF), Ministerstwa Kultury (jego Wydziału Badań i Technologii, Dyrekcji Dziedzictwa), Wydziału Muzealnego Ministerstwa Edukacji i Biura Współpracy i Informacji Muzeograficznej (OCIM) we Francji oraz ICCROM w Rzymie. Wykładowcy pochodzą m.in. z tych ośrodków oraz ICC/.CCI w Kanadzie.

2 Szczególnie: S. Keene, Audits of care, a framework for collections conditio surveys, Storage, Preprints to UKIC Conference Restoration '91, London 1991, s. 6-16; The conservation assessment, A tool for Planning, Implementing and Fundraising, red S. Wolf, National Institute for the Conservation of Cultural Property and Getty Conservation Institute, Washington 1991; La conservation préventive, $3^{\text {ème }}$ colloque de l'ARAAFU Paris-8,9 et 10 octobre 1992, Paris 1992; D. Guillemard, C. Laroque, Manuel de conservation préventive- gestion et contrôle des collections, OCIM, Dijon 1999; D. Guillemard, La conservation préventive, une alternative à la restauration des objets ethnographiques, Villeneuve d'Ascq 2000; D. Guillemard, Evaluation des conditions de conservation, Master de conservation préventive, document de cours, Université Paris I, (pdf), Paris 2008; B. de Tapol, De l'évaluation au plan de conservation préventive: réflexion sur l'évolution de la gestion de la préservation, „Conservation-Restauration des biens culturels”, nr 17-18, 2001, s. 81-94. Na bazie tego typu refleksji i doświadczeń powstały narzędzia w rodzaju Benchmarks in Collection Care for Museums, Archives and Libraries - dostęp w Internecie http:// www.collectionstrust.org.uk/benchmarks-in-collections-care/benchmarks-in-collection-carefor-museums-archives-and-libraries z dnia 31.12.2014. 
go polega na analizie zastanej rzeczywistości, postawieniu diagnozy, sformułowaniu zaleceń i stworzeniu szczegółowego planu działania służącego zmianie na lepsze ${ }^{3}$. „Audyt ukierunkowuje działanie, by przekształcić sytuację początkowa, odebrana jako nieodpowiednią lub niedoskonała, w lepszą sytuację końcową".

\section{Ewaluacje przeprowadzane w ramach audytu konserwatorskiego}

Celowo w kontekście audytu używane jest określenie „ewaluacja”, a nie np. „ocena” czy „ekspertyza”, gdyż nie oznacza ona opinii na temat faktów, a jest oceną wartościująca, osądem danej rzeczywistości dokonywanym względem wzorca. W przypadku konserwacji zapobiegawczej i różnorodnego dziedzictwa kulturowego nie istnieje jeden, ogólny i skodyfikowany model sytuacji wzorcowej. W samym procesie ewaluacji dotyczącym konkretnego przypadku (tj. funkcjonowania danej instytucji) kształtuje się, w oparciu o istniejące normy czy wskazania, układ odniesienia, model, ku któremu skierowane są dążenia poprawy sytuacji ${ }^{5}$.

Audyt konserwatorski zawierać może kilka rodzajów ewaluacji ${ }^{6}$. Mogą one również być przeprowadzane oddzielnie i niezależnie jako warto-

3 Taki audyt ma charakter perspektywiczny, tzn. ma prowadzić do zmiany zastanej sytuacji. Możliwe są także audyty o charakterze refleksyjnym, zwrotnym, służące ocenie zakładanych zmian ustalonego już wcześniej projektu (konserwatorskiego, edukacyjno-kulturalnego, projektu architektonicznego muzeum, magazynu) - wówczas kontrolowane są warunki realizacji celów nim określonych i zgodność zamierzeń projektu z normami i standardami; możliwe są też audyty służące ocenie postępu realizacji danego projektu.

4 Guillemard 2008, s. 3.

5 Wiele wskazań i standardów dotyczących m.in. warunków w otoczeniu dziedzictwa nie ma charakteru norm, choć w ostatnim czasie dochodzi do ujmowania ich w normach, np. EN 15757 ICS 97.195 Conservation of Cultural Property Specifications for temperature and relative humidity to limit climate-induced mechanical damage in organic hygroscopic materials, september 2010.

6 Przyjęto termin „ewaluacja”, rezygnując z określenia „ocena”, gdyż w polskiej praktyce konserwatorskiej kojarzy się on o z działaniami o węższym zakresie znaczeniowym, np. ocena stanu zachowania. W podobnie szerokim znaczeniu w odniesieniu do dóbr kulturowych jest ostatnio używane pojęcie „monitoring” - patrz: Wyjatkowa uniwersalna wartość 
ściujące oceny poszczególnych sfer odzwierciedlających proces „zachowania dziedzictwa kulturowego, przy jednoczesnym poszanowaniu jego znaczenia, w tym jego dostępności dla obecnych i przyszłych pokoleń”, czyli ich szeroko rozumianej konserwacji․ Zakres dokonywanej operacji warunkuja aktualne potrzeby danej instytucji muzealnej, archiwum czy innej gromadzącej, sprawującej opiekę i udostępniającej materialne dobra kultury.

Ewaluacja warunków konserwatorskich zbiorów (fr. évaluation des conditions de conservation, ang. conservation assessment) $\mathrm{w}$ rozumieniu środowiska fizycznego i funkcjonowania instytucji oraz funkcjonowania zbiorów w instytucji determinującego te warunki.

Ewaluacja stanu zbiorów (fr. évaluation des collections, ang. collections conditions survey) bazuje na materialnym rozpoznaniu zbiorów, oznaczającym określenie natury (typologii, gabarytów, liczebności) oraz ocenę stanu zachowania całości zbiorów, która, w zależności od sytuacji i potrzeb, dokonana może być w różny sposób ${ }^{8}$. Jest ro ewaluacja uzupełniająca ewaluację warunków konserwatorskich. Może być też przeprowadzana odrębnie, służąc np. ocenie ewolucji stanu zachowania obiektów, długoterminowemu zaprogramowaniu zabiegów konserwatorskich, reorganizacji magazynów i innych.

Ewaluacja znaczenia dla dziedzictwa (fr. évaluation de la valeur patrimoniale, ang. curatorial survey) polega na określeniu znaczenia poszczególnych obiektów wchodzących w skład zbiorów dla dziedzictwa, które reprezentują ${ }^{9}$ inaczej może być nazwana wartościowaniem (waloryzacja, oceną wartości) obiektów jako części zbiorów. Ten typ ewaluacji jest niezbędny do ustalania priorytetów działań konserwatorskich po dokonaniu oceny

a monitoring dóbr Światowego Dziedzictwa, red. B. Szmygin, Warszawa 2011. Kierując się jednak słownikowym a zarazem powszechnym rozumieniem tego pojęcia i faktem, że opisywane $\mathrm{w}$ artykule działania nie maja charakteru stałego nadzoru, uznano stosowanie terminu „ewaluacja” za bardziej adekwatne dla opisywanych działań.

Zgodnie z definicją „konserwacji” podawana w: Polska norma PN-EN 15898 Konserwacja dóbr kultury, ogólne terminy i definicje, PKN, Warszawa 2013, s. 10. Patrz też definicje konserwacji i konserwacji zapobiegawczej ICOM-CC, dostęp w Internecie: http://www.icom-cc. org/242/about-icom-cc/what-is-conservation/\#.U0PSPlcQPoQ z dn. 10 kwiecień 2014.

8 Zależnie od liczebności i typologii zbiorów metodą systematyczną, metodą zbiorów homogenicznych lub metodą statystyczna. Nt. metody statystycznej zob. Keene 1991, s. 10-11; Guillemard 2008, s. 28-29.

9 Keene 1991, s. 7. 
stanu zachowania zbiorów, przy rozdziale środków czy przy przygotowywaniu planów awaryjnych.

Audyt konserwatorski zależnie od rodzaju i celu, w jakim jest przeprowadzany, może wymagać dokonania różnych rodzajów ewaluacji. Obszar, jaki zostanie objęty audytem, definiowany jest wspólnie przez instytucję mu poddawaną i osobę czy zespół dokonujący audytu. W najszerszym wymiarze audyt konserwatorski mieści w sobie wszystkie trzy rodzaje ewaluacji, prowadząc do globalnej ewaluacji instytucji muzealnej czy innego podmiotu sprawującego opiekę nad dobrami kulturowymi i stworzenia osadzonego w konkretnych ramach czasowych całościowego planu jej przyszłego działania w zakresie konserwacji rozumianej jako „środki i działania służące zachowaniu dziedzictwa kulturowego"10. Różnica pomiędzy audytem konserwatorskim a samą tylko ewaluacją zawiera się w tym, że audyt nie kończy się samym stwierdzeniem odchyleń zastanej rzeczywistości od rzeczywistości pożądanej i wskazaniem tego przyczyn, lecz polega na przyjęciu postawy zaangażowanej poprzez sformułowanie nie tylko zaleceń, ale konkretnego, indywidualnego planu działania, który pozwoli tę rzeczywistość zmienić $^{11}$. Rozległość audytu konserwatorskiego, czyli zarazem zestaw ewaluacji podejmowanych w jego ramach, zależy od potrzeb i celu, w jakim się go dokonuje. W zależności od potrzeb danej instytucji w określonym momencie, może opierać się na ewaluacji warunków konserwatorskich, czyli warunków w otoczeniu zbiorów i zarządzania nimi, prowadząc do wskazania obecnych źródeł zagrożeń trwania zbiorów i skonstruowania planu poprawy sytuacji. Celem audytu może być także wyłącznie rozpoznanie wpływu budynku i zarządzania jego przestrzenią na warunki konserwatorskie czy też identyfikacja przyczyn degradacji zbiorów w dążeniu do jej zahamowania lub rozpoznanie potrzeb przestrzeni i organizacji magazynów służących przechowywaniu zbiorów. W każdym przypadku, w oparciu o konkretne dane i ich analizę, wartościującej ocenie należy poddać zestaw innego rodzaju wskaźników, czyli istotnych czynników i cech. Przykłady zestawiono w poniższej tabeli. Audyt konserwatorski od samej tylko ewaluacji różni prócz zaangażowanej postawy, o której już wspomnia-

10 Definicja konserwacji zawarta w: Polska norma PN-EN 15898 2013, s. 10.

11 Guillemard 2008, s. 4. 
no - rozległość, bardziej kompleksowy charakter, nie zawężony do oceny warunków fizycznych, ale obejmujący też w szerokim lub węższym stopniu zarządzanie zbiorami (dlatego też np. działanie polegające na osądzie rzeczywistości rozumianym wyłącznie jako ocena fizycznych warunków środowiska nie będzie audytem konserwatorskim).

\section{Metodyka i etapy audytu konserwatorskiego}

\section{Opis rzeczywistości}

\section{- system wskaźników, odniesień i ocen}

Podstawę do przeprowadzenia ewaluacji i audytu stanowi określenie zastanej rzeczywistości, czyli tych wszystkich zmiennych, które mają wpływ na otoczenie (środowisko) i użytkowanie zbiorów. Opis, który je relacjonuje w ramach audytu, nie odzwierciedla wszelkich możliwych detali tej rzeczywistości, zawiera tylko elementy znaczące i użyteczne, tj. te, które pozwolą postawić i wyjaśnić diagnozę.

Obraz danej rzeczywistości budowany jest poprzez kontrolę funkcjonowania, rozumianą jako określenie wpływu działalności instytucji (muzealnej) i warunków środowiska na zbiory, czyli wskazuje na związek przyczyn i skutków. W jej wyniku powstaje zbiór konkretnych informacji na temat warunków konserwatorskich w postaci parametrów i innych danych. Zbieranie informacji odbywa się za pośrednictwem wywiadu, ankiet, formularzy kontrolnych, przeprowadzania analiz stanu zachowania, wykazów danych uzyskanych metodą statystyczna, spisu zbiorów. Uzyskane dane maja charakter opisowy - jak na przykład opis stanu zachowania, określenie typów zniszczeń, ilościowy - jak rezultaty pomiarów fizycznego środowiska, inwentarz zbiorów, klasyfikacja według materiałów, oraz jakościowy - przedstawiający warunki konserwatorskie, procedury, kontrolę działań. Pozyskiwanie i selekcja informacji ukierunkowane sa poprzez cel, w jakim dokonywana jest ewaluacja, ich porządkowanie odbywa się dzięki zastosowaniu odpowiednich narzędzi - wskaźników.

Wskaźniki oznaczają: „dane lub zmienne obserwowalne, rozdzielne, możliwe policzalne, wybrane przez dokonującego ewaluacji jako odpo- 
wiadające określonym zaleceniom (regułom)"12. W celu przeprowadzenia ewaluacji i audytu konieczne jest użycie dwóch rodzajów wskaźników: wskaźników sytuacji i wskaźników funkcjonowania. Pierwsze z nich przedstawiaja materialne składowe danej rzeczywistości, tj. zastosowania, zjawiska fizyczne, drugie dotyczą jej elementów niematerialnych - działań, zachowań określonych dyspozycjami, regulaminami, zwyczajami, przyzwyczajeniami.

Tabela 1. Przykłady wskaźników sytuacji i funkcjonowania ${ }^{13}$

\begin{tabular}{|c|c|}
\hline Wskaźniki sytuacji & Wskaźniki funkcjonowania \\
\hline $\begin{array}{l}\text { Warunki materialne: } \\
\text { zastosowania w praktyce, zjawiska fizyczne, używane środ- } \\
\text { ki i materiały }\end{array}$ & $\begin{array}{l}\text { Warunki niematerialne, których efekty powstają w wyniku dzia- } \\
\text { łania: } \\
\text { przepisy, regulaminy, procedury, zwyczaje , przyzwyczajenia }\end{array}$ \\
\hline $\begin{array}{l}\text { - } \text { cechy budynku } \\
\text { - warunki środowiska i środki ich regulacji (klimat, oświetle- } \\
\text { nie, aparatura służąca regulacji) } \\
\text { - warunki ekspozycji (gabloty, postumenty, materiały w kon- } \\
\text { takcie z obiektami etc.) } \\
\text { - warunki transportu, manipulowania obiektami } \\
\text { - sposób przechowywania (sprzęt, metoda, materiały w kon- } \\
\text { takcie z obiektami) }\end{array}$ & $\begin{array}{l}\text { - bezpieczeństwo zbiorów: zabezpieczenia przed kradzieżą, } \\
\text { wandalizmem, zabezpieczenia przed pożarem, plan reago- } \\
\text { - wania w przypadku katastrof } \\
\text { - reguły funkcjonowania } \\
\text { - } \text { kwalifikacje personelu, plan szkoleń } \\
\text { - procedury wypożyczania, udostępniania do badań etc. }\end{array}$ \\
\hline
\end{tabular}

Zestaw wskaźników nie jest z góry określony dla wszystkich możliwych przypadków. Kształtowany jest odrębnie dla danego audytu konserwatorskiego i nie służy, jak już wspomniano, odwzorowaniu całej rzeczywistości danej instytucji sprawującej opiekę nad dziedzictwem kulturowym. Wybór, podlegający uzasadnieniu na wstępie audytu, dokonywany jest tak, by wskaźniki przedstawiały cechy, które uważamy za charakterystyczne i znaczące w rzeczywistości poddawanej ocenie. Selekcja determinowana jest przez zadanie, jakie ma spełnić ewaluacja czy audyt, i wybierane sa tylko te wskaźniki, które pozwalaja zobrazować istniejące problemy, a ułatwiając ich zrozumienie, przyczynią się do ich rozwiązania (patrz tabele 2 i 3 ).

12 Guillemard 2008, s. 6, za: M.-H. Broch, F. Cross, Évaluer le projet de notre organisation, Chronique Sociale, Lyon 1992, s. 74.

$13 \mathrm{Na}$ podstawie: Guillemard 2008, s. 9. 
Tabela 2. Przykładowe cele audytu konserwatorskiego, wskaźniki i niezbędne dane

\begin{tabular}{|c|c|c|c|}
\hline \multicolumn{2}{|r|}{ Cel audytu konserwatorskiego } & Wskaźniki & Niezbędne dane \\
\hline 1 & $\begin{array}{l}\text { Rozpoznanie wpływu budynku na warunki kon- } \\
\text { serwatorskie i możliwości korekty }\end{array}$ & $\begin{array}{l}\text { Cechy budynku: szczelność, izolacja, } \\
\text { ochrona przed wodą ciekłą. } \\
\text { Dostosowanie struktury do pełnionej } \\
\text { funkcji: trakty komunikacyjne, rozpla- } \\
\text { nowanie. }\end{array}$ & $\begin{array}{l}\text { Projekt architektoniczny, kon- } \\
\text { cepcja budynku. } \\
\text { Charakterystyka materiałów. } \\
\text { Plan zagospodarowania prze- } \\
\text { strzeni. }\end{array}$ \\
\hline 2 & $\begin{array}{l}\text { Identyfikacja przyczyn degradacji zbiorów w ce- } \\
\text { lu jej zahamowania }\end{array}$ & $\begin{array}{l}\text { Otoczenie zbiorów: przestrzeń, warun- } \\
\text { ki klimatyczne (wilgotność względna } \\
\text { i temperatura), warunki oświetlenio- } \\
\text { we, sanitarne (tzw. czystość mikrobio- } \\
\text { logiczna i zoologiczna). } \\
\text { Eksploatacja (użytkowanie) zbiorów: } \\
\text { wystawy i in., sposób ekspozycji/prze- } \\
\text { chowywania (sprzęty ekspozycyjne } \\
\text { i magazynowe, gabloty), manipulowa- } \\
\text { nie, konserwacja-restauracja, udostęp- } \\
\text { nianie do badań. }\end{array}$ & $\begin{array}{l}\text { Zarejestrowane dane pomiarowe } \\
\text { i wynikające z obserwacji. } \\
\text { Natura i „wrażliwość” zbiorów } \\
\text { - ich podatność na działanie } \\
\text { czynników niszczących. Roz- } \\
\text { poznanie zniszczeń i ich rozle- } \\
\text { głości. } \\
\text { Reguły zachowań i użytkowania, } \\
\text { kontrole działalności. }\end{array}$ \\
\hline 3 & $\begin{array}{l}\text { Rozpoznanie potrzeb przestrzennych magazyno- } \\
\text { wania zbiorów i propozycje rozwiązań }\end{array}$ & $\begin{array}{l}\text { Objętość zbiorów. } \\
\text { Funkcjonalność pomieszczeń. } \\
\text { Organizacja przestrzeni. } \\
\text { Ruch obiektów - wewnątrz instytucji } \\
\text { i wypożyczenia, dostęp. }\end{array}$ & $\begin{array}{l}\text { Koncepcja budynku. } \\
\text { Program działalności kultural- } \\
\text { nej, naukowej i edukacyjnej. } \\
\text { Polityka zarządzającego, budżet. } \\
\text { Inwentarz. }\end{array}$ \\
\hline 4 & $\begin{array}{l}\text { Ewaluacja warunków konserwatorskich - wska- } \\
\text { zanie obecnych źródeł zagrożeń trwania zbio- } \\
\text { rów i skonstruowanie planu poprawy sytuacji }\end{array}$ & Łącznie 1, 2 i 3. & Łącznie 1, 2 i 3. \\
\hline
\end{tabular}

Dziedziny odniesienia w stosunku do rzeczywistości danej instytucji muzealnej to obszary pozwalające dokonać wartościującej oceny z puntu widzenia konserwacji zapobiegawczej. Wzorcowe warunki w ich obrębie kształtowane są w oparciu o zespół norm ${ }^{14}$, reguł, wartości, zdefiniowanych przez odpowiednie teksty lub zbudowany dla danych okoliczności ${ }^{15}$, tworzący swego rodzaju repozytorium, pozwalające na dokonanie porów-

14 Norma jako zalecenie albo nakaz ustalane, by osiagnać określony cel, jakąś cechę lub zachowanie, ale nie jest celem samym w sobie. Nieporozumieniem jest traktowanie jej mechanicznie. Przykładowo odnośnie do warunków klimatycznych dla obiektów drewnianych: celem określanym normą jest odpowiednia wilgotność względna, pozwalająca na dobre zachowanie drewna, a nie jej wartość liczbowa (50\% +-5). - cyt. za: Guillemard 2008, s. 28.

15 Warunki konserwatorskie nie moga zostać określone jedynie przez zestaw norm wyrażanych w danych fizycznych, jako elementy mierzalne, obejmują też właściwości związane z zachowaniami, czyli czynnikiem ludzkim. 
nania między zastaną sytuacją a sytuacja pożądana - „idealną”. Przykładowo, poddając ewaluacji zarządzanie zbiorami, należy wziąć pod uwagę takie sfery, jak:

- funkcjonalność pomieszczeń (sal ekspozycyjnych, pomieszczeń do badań, konsultacji, magazynów), czyli ich zdolność pełnienia przypisanych im funkcji, w tym konfigurację pomieszczeń, adekwatność przestrzeni do przypisanych funkcji, rozmieszczenie funkcji i ich relacje, możliwości adaptacji przy zmieniających się zasobach;

- dostęp do zbiorów - determinowany tak przez cechy lokali i sprzętu i ich adaptowalność, jak i uporządkowanie zbiorów wynikające z wykorzystania przeprowadzonej klasyfikacji i istniejącej dokumentacji; ergonomię;

- zabezpieczenie zbiorów, zarówno eksponowanych, jak i magazynowanych - dostosowane do ich natury i podatności na oddziaływanie różnych czynników ryzyka i na niszczenie, obejmujące kontrolę i regulację wszelkich parametrów środowiska, adekwatność wszelkiego sprzętu i materiałów służących ekspozycji, przechowywaniu i konsultacji, zabezpieczenie przed pożarem i zalaniem, bezpieczeństwo;

- organizację i planowanie działań służących zachowaniu zbiorów - obejmujących programowanie aktywności instytucji w różnych sferach, organizację, szkolenia, kwalifikacje personelu i przyporządkowanie funkcji, specyfikację i kontrolę zadań zlecanych na zewnątrz, wymogi i środki związane z manipulowaniem obiektami, organizacją wystaw, zarządzaniem magazynami, zarządzaniem i przygotowaniem tranzytu i transportu, warunków wypożyczeń, kontrolę i dokumentację stanu;

- przepisy i procedury ułatwiające eksploatację zbiorów - określające poziomy dostępu oraz zasady i kontrolę dostępu do zbiorów, regulaminy, dokumentowanie zbiorów.

Każdej z nich przyporządkowany jest zespół wyselekcjonowanych wskaźników, odzwierciadlających istotne składowe w tych obszarach, który pozwoli dokonać oceny sytuacji.

Poniżej zaprezentowano zbiory wskaźników wybrane, w pierwszym przypadku, podczas audytu konserwatorskiego niewielkiego muzeum o zbiorach, z muzeograficznego i materiałowego punktu widzenia, bardzo 
różnorodnych ${ }^{16}, \mathrm{w}$ drugim - zestaw wskaźników opracowany dla audytów placówek muzealnych będących zabytkowymi teatrami zawierającymi i gromadzącymi kolekcje malarskich dekoracji scenicznych ${ }^{17}$. W pierwszym wypadku (A) audyt miał węższy zakres, miał udzielić odpowiedzi na pytanie o zagęszczenie zbiorów i potrzeby magazynowe oraz warunki środowiskowe (fizyczne) zbiorów i ich stan, w drugim przypadku (B) służył ewaluacji całości warunków konserwatorskich kolekcji. W pierwszym wypadku wytypowano dziewięć, w drugim - szesnaście wskaźników, z których pierwsze dziewięć dotyczyło wpływu zarządzania kolekcją na jej funkcjonowanie i stan, a kolejne - warunków środowiskowych kolekcji.

Tabela 3. Przykłady zestawów wskaźników w różnych rodzajach audytu

\begin{tabular}{|c|c|}
\hline Audyt konserwatorski $\mathrm{A}$ & Audyt konserwatorski B \\
\hline $\begin{array}{l}\text { Rozpoznanie i znajomość zbiorów -inwentarz } \\
\text { Wpływ stanu budynku na zbiory } \\
\text { Warunki klimatyczne } \\
\text { Warunki oświetleniowe } \\
\text { Zabezpieczenia przed pożarem } \\
\text { Bezpieczeństwo zbiorów } \\
\text { Zaangażowanie w zadania konserwacji zapobiegawczej } \\
\text { Stan zbiorów - konieczność poddania zabiegom } \\
\text { Zagęszczenie i sposób przechowywania nieeksponowanej czę- } \\
\text { ści zbiorów }\end{array}$ & $\begin{array}{l}\text { Usytuowanie kolekcji w polityce instytucji } \\
\text { Wpływ udostępniania zbiorów na ich stan } \\
\text { Planowanie i przeprowadzanie działań konserwatorskich: zapo- } \\
\text { biegawczych, zachowawczych, restauratorskich } \\
\text { Kwalifikacje i motywacja personelu } \\
\text { Zabezpieczenie przed pożarem } \\
\text { Zabezpieczenie przed szkodami powodowanymi przez wodę } \\
\text { Kontrola warunków klimatycznych } \\
\text { Bezpieczeństwo zbiorów: zabezpieczenie przed włamaniem } \\
\text { i wandalizmem } \\
\text { Zabezpieczenia na wypadek katastrof - plan awaryjny } \\
\text { Dostęp do elementów zbioru } \\
\text { Sposób przechowywania i/lub ekspozycji oraz prezentacji } \\
\text { Manipulowanie obiektami, tj. sposób obchodzenia się z nimi } \\
\text { podczas przemieszczania } \\
\text { Utrzymanie higieny pomieszczeń } \\
\text { Obecność zakażeń i szkodników (inaczej czystość mikrobiolo- } \\
\text { giczna i zoologiczna) i skuteczność ich kontroli } \\
\text { Warunki klimatyczne i skuteczność ich regulacji } \\
\text { Ekspozycja na działanie światła }\end{array}$ \\
\hline
\end{tabular}

16 Hélène Guillaut, Anne Lama, Elżbieta. Szmit-Naud, Musée de Gallé- Juillet - évaluation en conservation préventive (opracowanie w formie prezentacji multimedialnej), Paris 2006, Université Paris I Panthéon-Sorbonne U.F.R., Histoire de l'Art et Archéologie, Paris.

17 E. Szmit-Naud, Préservation des décors historiques de théatre: un défi pour la conservation préventive, Exemple du Théâtre de la Reine à Versailles, (kps), Paris 2006, s. 35-60, Université Paris I Panthéon-Sorbonne U.F.R., Histoire de l'Art et Archéologie, Paris; E. Szmit-Naud, Kolekcje dekoracji teatralmych jako wyzwanie dla konserwacij zapobiegawczej na prayktadzie dekoracji sceny wtoskiej w Europie, (kps, rozprawa habilitacyjna ), Toruń 2013, s. 292-314. 


\section{Wartościująca ocena - ewaluacja}

Ewaluacji dokonuje się, oceniając wskaźniki charakteryzujące daną rzeczywistość przez odniesienie ich do wzorców. Ocena taka pozwala określić, jak bardzo fragmenty danej rzeczywistości, określane danymi wskaźnikami, odbiegają od sytuacji, do której dążymy. Sama ocena wyrażona jest liczbowo stopniami. Każdy wskaźnik oceniany jest w tej samej skali, by umożliwić zestawianie ocen ze sobą i klarowne podsumowania. Stopniom odpowiada słowny osąd. Skala ocen na ogół konstruowana jest wzrastająco, tj. przez przyporządkowanie wyższym wartościom liczbowym lepszej oceny, choć spotykane są też klasyfikacje odwrotne. Jednak pierwszy sposób wydaje się bardziej wskazany, gdyż intuicyjnie lepszą sytuację kojarzymy z wyższymi liczbami. Każdorazowo skala ocen powinna być przedstawiona, gdyż słowne oceny przypisywane stopniom nie muszą mieć charakteru uniwersalnego i nie muszą każdorazowo sygnalizować takiego samego odchylenia od sytuacji wzorcowej. Przykładowo:

\begin{tabular}{|c|c|c|c|c|c|}
\hline Stopień & \multicolumn{5}{|c|}{ Ocena - osąd } \\
\hline 4 & dobry & lub & dobry & lub & bardzo dobry \\
\hline 3 & średni & & średni & & dobry \\
\hline 2 & zły & & zły & & średni lub dopuszczalny \\
\hline 1 & niedopuszczalny & & bardzo zły & & zły \\
\hline
\end{tabular}

Uzasadnienie oceny w przypadku każdego ze wskaźników przedstawiają opisowo scharakteryzowane kryteria, w myśl jednolitej zasady odzwierciadlającej skalę oceny. Formułowane sa z osobna i indywidualnie w przypadku każdej ewaluacji przeprowadzanej w ramach audytu dla danego wskaźnika. W ten sposób każda z ocen w przypadku konkretnych wskaźników obrazuje stan jej odpowiadający, z zasygnalizowaniem przyczyn. W odniesieniu do ewaluacji warunków konserwatorskich zbiorów system oceny w ogólnym zarysie przedstawić można następująco ${ }^{18}$ :

18 Na podstawie: Guillemard 2008, s. 11. 


\begin{tabular}{|l|l|}
\hline \multicolumn{1}{|c|}{ Stopnie } & \multicolumn{1}{c|}{ Kryteria } \\
\hline 4: dobry & $\begin{array}{l}\text { Warunki w otoczeniu (materialne i niematerialne - stwarzane przez sposób zarządzania zbiorami) nie } \\
\text { wpływają negatywnie na zbiory. Ślady zniszczeń są dawne, obiekty obecnie w stanie dobrym i stabil- } \\
\text { nym, są w pełni dostępne i udostępniane. }\end{array}$ \\
\hline 3: średni & $\begin{array}{l}\text { Warunki (jw.) mogą sprzyjać wystąpieniu zniszczeń (destabilizują zbiory) lub już zaczynają powodować } \\
\text { degradację części zbiorów, dostęp do zbiorów i ich dostępność są częściowe. }\end{array}$ \\
\hline 2: zły & $\begin{array}{l}\text { Warunki (jw.) powodują bieżącą degradację części zbiorów, następuje utrata integralności, co ogranicza } \\
\text { dostępność i możliwości udostępniania zbiorów. }\end{array}$ \\
\hline 1: niedopuszczalny & $\begin{array}{l}\text { Warunki (jw.) powodują postępującą degradację zbiorów, znaczna część obiektów ulega już niszczeniu } \\
\text { bądź jest w stanie niestabilnym, utrata integralności czyni zbiory niedostępnymi; }\end{array}$ \\
\hline
\end{tabular}

gdzie: „integralność - stopień fizycznej lub konceptualnej całości obiektu”19 i „dostępność dobra kulturowego” (zbiorów obiektów, które je stanowia) oznacza „ramy prawne i administracyjne, trwałe lub przejściowe, umożliwiające jego naukowe wykorzystanie, czyli wszelkie środki pozwalające dobrom kulturowym stać się źródłem wiedzy, czyniąc je dostępnymi dla osób zobowiązanych do ich publicznego upowszechniania (co obejmuje takie działania, jak: stworzenie depozytu czy zbiorów, spowodowanie włączenia obiektów do zbiorów, zgromadzenie dokumentacji, wykonanie inwentarza... ...)”20. Termin „degradacja” używany jest w znaczeniu procesu destrukcji materii, pojawiającego się, gdy równowaga pomiędzy dobrem kulturowym (tu - obiektami w zbiorach) i jego otoczeniem jest zachwiana lub warunki stwarzane przez sposób ich eksploatacji nie są właściwe ${ }^{21}$.

Dla przykładu poniżej przedstawiono, jaką formę może przybierać ocena poszczególnych wskaźników w konkretnej rzeczywistości ewaluowanej instytucji. Pierwszy przykład zaczerpnięto z audytu konserwatorskiego odnoszącego się do warunków konserwatorskich kolekcji zabytkowych iluzjonistycznych dekoracji scenicznych z Teatru Marii-Antoniny w Wersalu ${ }^{22}$. Przedstawiony wskaźnik jest jednym z szesnastu, które wybrano jako reprezentatywne dla ewaluowanej rzeczywistości. Odnosi się do sfery zarzą-

19 PN-EN 15898 2013, s. 9.

20 Cyt. za: D. Guillemard, Conservation préventive + glossaire, document du cours, Master professionnel de Conservation préventive Université de Paris I, (mps), Paris 2005, s. 2.

21 Ibidem, s. 1.

22 Szmit-Naud 2006, s. 38; Szmit-Naud 2013, s. 299. 
dzania zbiorami, a konkretniej - przyjętych i praktykowanych sposobów udostępniania i wyraża się w ich wpływie na stan kolekcji:

\begin{tabular}{|c|c|}
\hline \multicolumn{2}{|r|}{ Wskaźnik: Wpływ udostępniania kolekcji na jej stan } \\
\hline \multicolumn{2}{|r|}{ Dziedzina odniesienia: zarządzanie kolekcją - konserwacja, procedury konserwatorskie } \\
\hline Stopień & Kryteria \\
\hline 4 & $\begin{array}{l}\text { Zapewniona równowaga między sposobem udostępniania i zabezpieczeniem kolekcji, pozwala utrzymać ją w sta- } \\
\text { nie stabilnym. }\end{array}$ \\
\hline 3 & $\begin{array}{l}\text { Ogólne wymogi zabezpieczenia kolekcji uwzględniane w programowaniu jej udostępniania, niewystarczająca bie- } \\
\text { żąca rewidująca refleksja. }\end{array}$ \\
\hline 2 & Dominacja udostępniania nad dbałością o ochronę (zabezpieczenie dobrego trwania) kolekcji. \\
\hline 1 & $\begin{array}{l}\text { Stosowanie sposobów udostępniania kolekcji nierespektujących wymogów jej ochrony, prowadzące do jej de- } \\
\text { gradacji. }\end{array}$ \\
\hline
\end{tabular}

Inny przykład, zaczerpnięty z tego samego audytu, także mieszczący się w sferze zarządzania, dotyczący zabezpieczenia przeciwpożarowego ${ }^{23}$ :

\begin{tabular}{|c|c|}
\hline \multicolumn{2}{|c|}{ Wskaźnik: Zabezpieczenie przed pożarem } \\
\hline \multicolumn{3}{|c|}{ Dziedzina odniesienia: zarządzanie kolekcją - konserwacja - procedury konserwatorskie } \\
\hline Stopień & \multicolumn{1}{|c|}{ Kryteria } \\
\hline 4 & $\begin{array}{l}\text { Funkcjonujący, sprawny system przeciwpożarowy, instalacja elektryczna zgodna z obowiązującymi przepisami, wy- } \\
\text { starczające wyposażenie w środki zwalczania pożaru. }\end{array}$ \\
\hline 3 & $\begin{array}{l}\text { Środki zabezpieczenia przeciwpożarowego regularnie sprawdzane, instalacja elektryczna systematycznie dostoso- } \\
\text { wywana do obowiązujących norm. }\end{array}$ \\
\hline 2 & $\begin{array}{l}\text { Stosowane pewne środki i procedury przeciwpożarowe, nieregularnie lub niekompletnie sprawdzane, instalacja elek- } \\
\text { tryczna niecałkowicie zgodna z normami. }\end{array}$ \\
\hline 1 & $\begin{array}{l}\text { Całkowity brak środków ochrony przeciwpożarowej oraz procedur postępowania, instalacja elektryczna niezgod- } \\
\text { na z obowiązującymi normami. }\end{array}$ \\
\hline
\end{tabular}

W innych warunkach kryteria uzasadniające ocenę i zarazem wskazujące na charakter niedociagnięć mogą być wyrażone w odmienny sposób, jak w poniższym przykładzie $\mathrm{z}$ audytu obejmującego ewaluację warunków konserwatorskich i funkcjonalność budynku Centrum Archiwów Architektury XX wieku w Paryżu²4:

\footnotetext{
23 Szmit-Naud 2013, s. 300-301.

24 Dominique Barrièrre, Hélène Guillaut, Elżbieta Szmit-Naud, Le Centre d'Architecture du XX ${ }^{\text {ème }}$ siècle, Evaluation di bâtiment et des conditions de conservation, (opracowanie
} 


\begin{tabular}{|c|c|}
\hline \multicolumn{2}{|c|}{ Wskaźnik: Zabezpieczenie przed pożarem } \\
\hline \multicolumn{3}{|c|}{ Dziedzina odniesienia: zarządzanie kolekcją - konserwacja - procedury konserwatorskie } \\
\hline Stopień & \multicolumn{1}{c|}{ Kryteria } \\
\hline 4 & Pełne wyposażenie przeciwpożarowe i przestrzegane reguły przeciwpożarowe. \\
\hline 3 & Pełne wyposażenie przeciwpożarowe, ale brak przestrzegania reguł przeciwpożarowych. \\
\hline 2 & Istniejące środki przeciwpożarowe nie umożliwiają wykrywania pożaru. \\
\hline 1 & Całkowity brak środków ochrony przeciwpożarowej. \\
\hline
\end{tabular}

\section{Analiza i diagnoza}

Zsumowanie ocen wszystkich wskaźników pozwala przedstawić ogólną skuteczność w ewaluowanym obszarze, a ich zestawienie obok siebie - uczytelnić zarówno słabsze, jak i mocniejsze strony ewaluowanej rzeczywistości. Jednak poprzestanie na tego rodzaju zestawieniach oznaczałoby samo tylko zinwentaryzowanie przyczyn zniszczeń. Dokonanie ewaluacji służy postawieniu diagnozy, co oznacza wyjście poza stwierdzenie odchyleń od sytuacji pożądanej oraz drogę ku wskazaniu ich znaczenia i powiązaniu zagrożenia niszczeniem lub pojawiających się już objawów niszczenia z konkretnymi przyczynami i czynnikami. Zestawienie informacji uzyskanych na drodze ewaluacji warunków konserwatorskich i ewaluacji stanu zbiorów pozwala zidentyfikować, czy problemy ulokowane są w sferze niekorzystnych warunków fizycznych środowiska (np. źle bądź w ogóle nieregulowanych, wynikających tak z cech lokali, jak i z niewłaściwej regulacji przepływu zwiedzających), czy wynikaja z wad infrastruktury, tj. cech samego budyn$\mathrm{ku}$, jego koncepcji, czy są to problemy techniczne związane z organizacja i wielkością przestrzeni, w której znajduja się zbiory, czy też mają charakter instytucjonalny i organizacyjny (np. wynikający z niejasno lub źle określonych funkcji i zakresu odpowiedzialności, cięć budżetowych), czy też problem dotyczy samego personelu - kwalifikacji nieodpowiadających zakresowi obowiązków, braku kompetencji, niedostatecznego przeszkolenia albo dotyczy jego postaw - np. braku zainteresowania, motywacji. Analiza

w postaci prezentacji multimedialenej), Paris 2006, s. 59, Université Paris I Panthéon-Sorbonne U.F.R., Histoire de l'Art et Archéologie, Paris. 
dokonywana w trakcie diagnozowania sytuacji pozwala dostrzec ewentualne związki między stwierdzonymi problemami i znaczenie poszczególnych problemów w całym systemie. Pozwala na określenie, czy jedne problemy sa przyczynami bądź konsekwencjami drugich (np. zła organizacja przestrzeni i powstawanie mikroklimatów sprzyjających niszczeniu, brak przeszkolenia lub określonych reguł postępowania i niewłaściwe przemieszczanie obiektów skutkujące zniszczeniami itd.) oraz w jakim stopniu rozwiązanie danego problemu zadecyduje o poprawie funkcjonowania całości, tj. dla jak dużej części zbiorów wprowadzenie zmiany będzie korzystne, jaka część personelu będzie w nią zaangażowana. Dopiero wyraźne wskazanie związków stwierdzonych problemów i ich przyczyn pozwala na postawienie diagnozy, a następnie zaplanowanie adekwatnych rozwiązań.

\section{Sposoby prezentacji diagnozy}

Stosowane są różne sposoby formalizacji diagnozy - opisowe, tabelaryczne, graficzne. Najprostsza forma opisowa polega na krótkim nazwaniu problemów i opatrzeniu ich komentarzami wyłuszczającymi zasadnicze kwestie.

Bardziej rozubudowaną, czytelną formą pozwalająca przedstawić szczegóły diagnozy jest ukazanie w tabeli całej ewaluowanej rzeczywistości, uporządkowanej według obszarów i identyfikującej mocne i słabe oraz niepewne punkty w ich obrębie bądź przedstawiającej te same informacje, ale w sposób perspektywiczny, tj. wskazując niedociąnięcia, atuty i możliwości, a na końcu podsumowując globalnie słabe i mocne strony, istniejący potencjał i wskazując kierunek oczekiwanej ewolucji.

Graficzne zobrazowanie diagnozy umożliwia uzyskanie jednoczesnego wglądu w różne sfery określające ewaluowaną rzeczywistość, pozwala zobaczyć ja jako system zbudowany z różnych składników, pozwala dostrzec relacje między nimi, relacje między różnymi czynnikami oraz skutkami i postawić hipotezy. Jedną z możliwości jest użycie narzędzia stworzonego do tego celu, czyli przeprowadzenie analizy i przedstawienie diagnozy za pomoca wykresu Ishikawy, inaczej diagramu przyczyn i skutków, zwanego też diagramem rybiej ości. Jego pozioma oś przedstawia główny problem, duże boczne, dolne i górne odgałęzienia - ewaluowane obszary, czyli lokalizacje poszczególnych przyczyn wystąpienia problemu (np. gdy problem mieści się 
w zarządzaniu zbiorami będą to: funkcjonalność lokali, dostęp do zbiorów, zabezpieczenie zbiorów itd.) „wyrastające” z nich mniejsze odgałęzienia przyczyny w obrębie tych obszarów. Możliwe są też warianty tego diagramu uczytelniające diagnozę, w których można - symetrycznie względem głównej osi lub też jej odgałęzień - przedstawić wady i zalety dotyczące ewaluowanego zagadnienia.

Wskazany typ diagramu pozwala na systematyczne i hierarchiczne przedstawienie przyczyn problemu i związków między nimi, może jednak przy bardzo rozbudowanym audycie konserwatorskim być mało przejrzysty. Prócz niego stosowane sa inne, prostsze formy graficzne, pozwalające zobrazować całą ewaluowaną rzeczywistość i dostrzec zależności, np. wykresy radarowe ukazujące na poszczególnych osiach rezultaty ewaluacji poszczególnych wskaźników. Poniżej przedstawiono graficznie w ten sposób diagnozę dokonaną w ramach audytu konserwatorskiego opartego na ewaluacji warunków konserwatorskich kolekcji na przykładach z własnej praktyki - przywoływanych wcześniej audytów dotyczących muzeum w Creil (audyt konserwatorski A) oraz wykonanego dla jednej z kolekcji malarskich dekoracji scenicznych (audyt konserwatorski B) ${ }^{25}$.

\section{Zalecenia a jakość audytu}

Pierwsze z opisanych powyżej czynności przeprowadzanych w ramach audytu i ewaluacji mogą, a nawet musza, być dokonywane we współpracy z pracownikami instytucji, której audyt konserwatorski dotyczy. W fazie kolejnej, w której formułowane sa zalecenia, aby spełniły one swoje zadania, konieczna jest całkowita niezależność osób dokonujących ewaluacji, bez jakiegokolwiek wpływu czy uczestnictwa strony poddawanej audytowi. Od tej fazy audytu zależy jego efektywność. Nawet najlepiej przeprowadzona ewaluacja, analiza i diagnoza jej nie gwarantują ani nie są równoważne z dobrą jakością audytu konserwatorskiego. Decydująca jest jakość sformułowanych zaleceń. Zasadza się ona na ich celności oraz sposobie przekazu, który mu-

\footnotetext{
25 Przykład jednej z trzynastu kolekcji poddanych ewaluacji w oparciu o zaproponowany system wskaźników. Szmit-Naud 2013, s. 272-274, 314, zał. F oraz niepublikowane dane autorki.
} 
si trafiać do przekonania odbiorcy i uzmysławiać, że zalecenia są wykonalne, nie znajduja się poza pułapem możliwości. Tylko wówczas stanowia zachętę do podjęcia rzeczywistych działań. Powinny odgrywać rolę „wyzwalaczy" działania i jego regulatorów i włączać interesariuszy w ich przeprowadzanie. Zalecenia wynikające bezpośrednio z postawionej diagnozy moga zostać przedstawione bezpośrednio po jej opisie, mogą też dla większej czytelności i w sposób konkretny zostać zasygnalizowane bezpośrednio po przedstawieniu ewaluacji poszczególnych wskaźników, jak w przykładzie przedstawionym poniżej, który dotyczy zabezpieczenia przed włamaniem i wandalizmem, jest zaczerpnięty $\mathrm{z}$ własnej praktyki audytu konserwatorskiego dotyczącego jednej z kolekcji zabytkowych iluzjonistycznych dekoracji scenicznych przechowywanych w zabytkowym teatrze, udostępnianym widzom. Stan zabezpieczeń oceniono następująco:

\begin{tabular}{|c|l|}
\hline \multicolumn{2}{|c|}{ Wskaźnik: Zabezpieczenia przed włamaniem i wandalizmem } \\
\hline \multicolumn{2}{|c|}{ Dziedzina odniesienia: zarządzanie kolekcją - konserwacja - procedury konserwatorskie } \\
\hline Stopień & \multicolumn{1}{|c|}{ Kryteria: } \\
\hline 4 & $\begin{array}{l}\text { Cała kolekcja objęta systemem alarmowym skonfigurowanym w sposób dostosowany do jej funkcjonowania, } \\
\text { w przypadku obecności publiczności zapewniona odpowiednia ochrona. }\end{array}$ \\
\hline 3 & $\begin{array}{l}\text { Kolekcja chroniona przez służby ochrony odpowiednio wykwalifikowane, zapewniona minimalna liczba osób pil- } \\
\text { nujących w czasie udostępniania. }\end{array}$ \\
\hline 2 & $\begin{array}{l}\text { Kolekcja chroniona przez służby ochrony, lecz procedury, kwalifikacje lub/i liczba osób pilnujących niezapewnia- } \\
\text { jąca całkowicie skutecznej ochrony. }\end{array}$ \\
\hline 1 & Kolekcja bez ochrony, system zamknięć zawodny. \\
\hline
\end{tabular}

Ponieważ zaobserwowano, że zwiedzającym udaje się wymykać w strefy nieobjęte trasa zwiedzania, zalecono: „Poprawy wymaga koordynacja działań w związku z nowym sposobem funkcjonowania kolekcji (tj. sezonowego udostępnienia w ramach zwiedzania teatru przez kolejno napływające grupy). Prócz obecności jednego pracownika na miejscu konieczny jest drugi pracownik pomocniczy towarzyszacy grupie”. 
Samo sformułowanie zaleceń nie wystarcza do uruchomienia procesu zmian. Konieczne jest ich odpowiednie uporządkowanie, umożliwiające praktyczną aplikację zaleceń - stworzenie planu działania ${ }^{26}$.

\section{Plan działania - hierarchizacja zadań i strategia}

Plan działania stanowi narzędzie dokonywania zmian, poprawy rzeczywistości poddanej ewaluacji w ramach audytu konserwatorskiego. Jego tworzenie polega na uporządkowaniu czynności w czasie i w sposób zhierarchizowany. O hierarchii działań stanowi to, jak ważna jest dana czynność oraz jak pilna jest potrzeba jej wykonania. Czynności zostaja zorganizowane w trzech kategoriach grupujących zadania krótko-, średnio- i długoterminowe. Bardzo istotne jest zaplanowanie ich tak, by wpływały motywująco na zespół, który ma dokonywać zmian, pamiętając, że zadania pilne zawsze są ważne i muszą zostać podjęte bez sztywnego przesądzania o czasie ich trwania, a z kolei nie wszystkie zadania ważne należą do pilnych.

Zadania krótkoterminowe powinny zostać podjęte w czasie kilku dni, tygodni, ewentualnie kilku miesięcy. Zawierają czynności pilne lub/i nie wymagające dużych nakładów, punktowe. Dzięki temu, że ich efekty są natychmiastowe, zachęcaja i wprowadzaja w czynności następne.

Zadania średnioterminowe powinny zawierać się w okresie od jednego roku do trzech lat, Przygotowują do kolejnych prac, także zawierają działania pilne. Służą zdynamizowaniu ekipy, polegają na stopniowym pokonywa-

\footnotetext{
26 Tworzeniu planu działania w ramach audytu konserwatorskiego przyświeca ten sam cel co „projektowaniu konserwatorskiemu”, które wg normy jest „narzędziem zarządzania stosowanym do koordynacji środków i działań konserwatorskich” - PN-EN 15898, s. 14. W przypadku planowania działań w audycie konserwatorskim chodzi jednak o „działania konserwatorskie" w rozumieniu szerokim, nieograniczone do sfery warunków materialnych oddziałujących na zbiory i zadań z zakresu konserwacji-restauracji (te mogą stanowić jeden z jego elementów). Opis koncepcji programowania konserwatorskiego: B. J. Rouba, Proces ochrony dóbr kultury, pojecia, terminologia, [w:] Ars longa-vita brevis. Tradycyjne i nowoczesne metody badania dziet sztuki. Materiaty z. sesji nankowej pośmięconej pamięci Profesora Zbigniewa Brochwicza, red. J. Flik, Toruń 2003, s. 349-378 i szczegółowo: B. J. Rouba, Projektowanie konserwatorskie, „Ochrona Zabytków”, 2008, z. 1, s. 57-78).
} 
niu trudności, otwierającym pole do działań długoterminowych, a dotyczą zadań codziennych i ich organizacji.

Długoterminowe działania moga być rozłożone w perspektywie pięciu lat i dłuższej, dotyczą kwestii fundamentalnych, strukturalnych i strategicznych, czyli zasadniczej organizacji i zarządzania. Rzutują na przyszłość, wymagają dużych nakładów. Określenie „długoterminowe” nie oznacza koniecznie podjęcia ich realizacji w dalekiej perspektywie, mogą rozpocząć się na samym wstępie, nie należąc jednak do pilnych.

Hierarchiczne i strategiczne zaplanowanie zadań uczytelnia przedstawienie ich w matrycy $\mathrm{ABC}^{27}$, służącej właśnie ustaleniu priorytetów z punktu widzenia ważności i pilności potrzeb. W wariancie matrycy dostosowanym do potrzeb konserwacji zapobiegawczej klasyfikacja zadań ujętych w planie działania będący wynikiem audytu konserwatorskiego przedstawia się następująco ${ }^{28}$ :

działania typu A - bardzo pilne, oznaczaja przeciwdziałanie poważnemu niszczeniu zbiorów i eliminację najpoważniejszych zagrożeń;

działania typu B należą do ważnych, ale nie pilnych - chodzi o likwidację takich przyczyn zniszczeń, których oddziaływanie jest długotrwałe i kumulujące się, przykładowo takich jak nieuregulowane warunki klimatyczne w otoczeniu zbiorów, nieodpowiednie oświetlenie;

działania typu C nie są pilne, oznaczaja korekty, usuwanie nieprawidłowości o mniejszym znaczeniu, których trwanie i kumulacja daje jednak szkodliwe efekty. Moga to być pewne braki w procedurach pozwalające np. na ścieśnienie obiektów w miejscu ich przechowywania, umieszczanie w magazynie „obcych” materiałów czy przedmiotów, luki w przeszkoleniu personelu.

27 Będącej pochodną macierzy (matrycy) Heisenhovera, czyli Dwigtha Davida Heisenhovera, późniejszego prezydenta USA, gdzie czynności A określone były jako pilne i ważne, bardzo znaczące dla osiagnięcia zamierzonych celów, czynności B - ważne, ale nie tak pilne i nie kończące się w krótkim czasie, $\mathrm{C}$ - pilne, ale mało ważne oraz D - niepotrzebne.

28 Za: Guillemard 2008, s. 18. 
Tabela 4. Priorytety działań - matryca ABC

\begin{tabular}{|c|c|c|c|c|}
\hline \multicolumn{5}{|c|}{ TERMINY } \\
\hline \multirow{3}{*}{ WAŻNOŚĆ } & & KRÓTKI & ŚREDNI & D \\
\cline { 2 - 5 } & BARDZU WAŻNE & $\mathrm{A} 1$ & $\mathrm{~A} 3$ & $\mathrm{~B} 2$ \\
\cline { 2 - 5 } & WAŻNE & $\mathrm{A} 2$ & $\mathrm{~B} 1$ & $\mathrm{~B} 3$ \\
\cline { 2 - 5 } & MNIEJ WAŻNE & $\mathrm{C} 1$ & $\mathrm{C} 2$ & $\mathrm{C} 3$ \\
\hline
\end{tabular}

Plan działań przygotowywany w ramach audytu konserwatorskiego nie zawiera ogólnikowych stwierdzeń, gdyż oznaczałby wówczas jedynie uporządkowanie zaleceń. Prócz ustalenia priorytetów, czyli uszeregowania konkretnych czynności zgodnie z hierarchią ważności i pilności, wskazuje na jednostki odpowiedzialne za ich wykonanie i uczestników oraz określa niezbędne zasoby. Poniżej zacytowano, fragmentarycznie, przykłady czynności ujętych w planach działań krótko-, średnio- i długoterminowych przygotowanych dla jednej z instytucji dysponujących zbiorami zabytkowych dekoracji teatralnych, w której dokonano konserwatorskiego audytu.

Tabela 5. Przykład planów działań krótko-, średnio- i długoterminowych

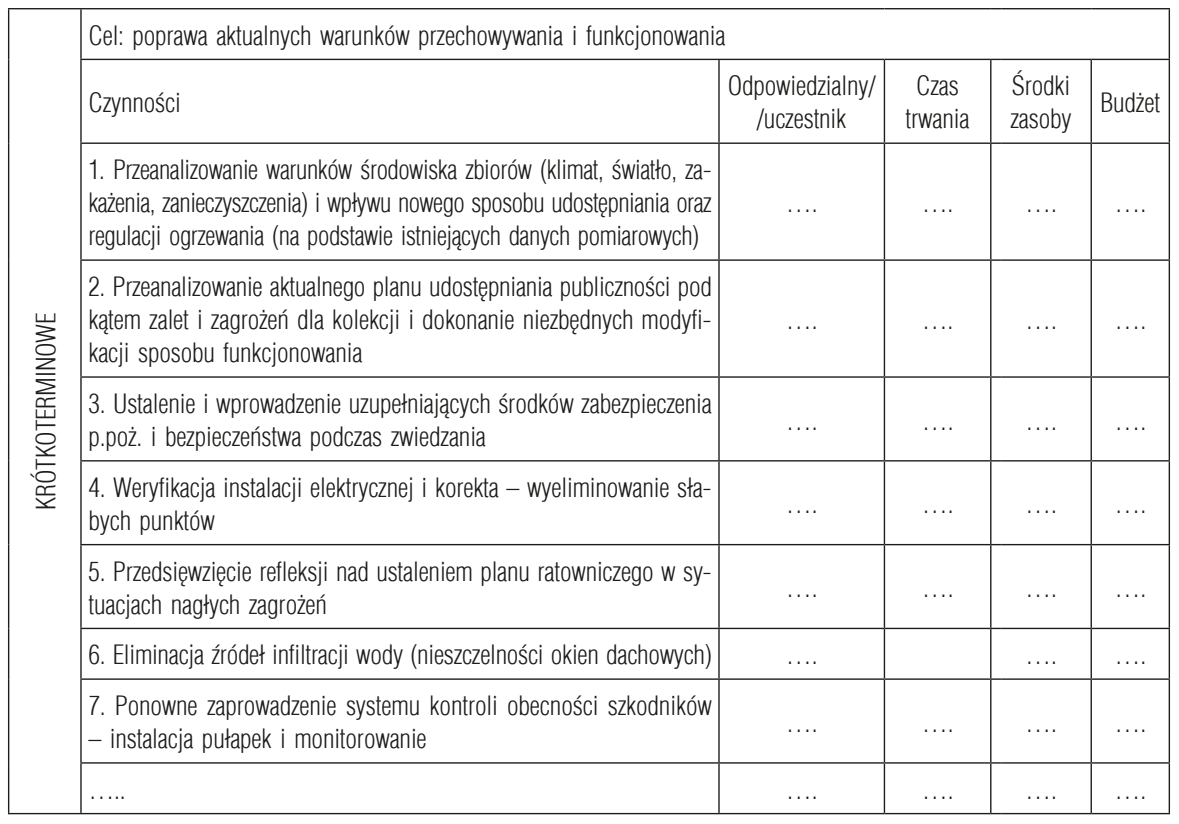




\begin{tabular}{|c|c|c|c|c|c|}
\hline \multirow{7}{*}{ 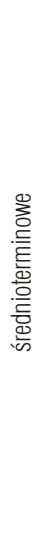 } & \multicolumn{5}{|c|}{ Cel: przygotowanie odpowiedniego systemu przechowywania najbardziej osłabionej i nieeksponowanej części kolekcji } \\
\hline & Czynności & $\begin{array}{l}\text { Odpowiedzialny/ } \\
\text { /uczestnik }\end{array}$ & $\begin{array}{l}\text { Czas } \\
\text { trwania }\end{array}$ & $\begin{array}{l}\text { Środki } \\
\text { zasoby }\end{array}$ & Budżet \\
\hline & 1. Określenie liczby i sposobu prezentacji dekoracji na scenie teatru & $\ldots$ & $\ldots$ & $\ldots$ & .... \\
\hline & $\begin{array}{l}\text { 2. Oszacowanie niezbędnej powierzchni dla modułów systemu prze- } \\
\text { chowywania }\end{array}$ & $\ldots$ & $\cdots$ & $\ldots$ & $\ldots$ \\
\hline & $\begin{array}{l}\text { 3. Zaprojektowanie i wykonanie boksów na elementy dekoracji po- } \\
\text { zwalających na bezpieczne manipulowanie i ograniczenie uszkodzeń } \\
\text { mechanicznych }\end{array}$ & $\ldots$ & $\ldots$ & $\cdots$ & $\ldots$ \\
\hline & $\begin{array}{l}\text { 4. Zaprojektowanie i wykonanie w tylnej partii I poziomu nadscenia } \\
\text { stelażu na rulony dekoracji zwieszanych }\end{array}$ & $\cdots$ & $\cdots$ & $\cdots$ & $\ldots$ \\
\hline & $\begin{array}{l}\text { 5. Wykonanie kopii zwieszanych elementów dekoracji pochodzących } \\
\text { z zestawów prezentowanych na scenie }\end{array}$ & ... & ... & $\ldots$ & \\
\hline \multirow{9}{*}{ 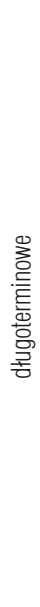 } & \multicolumn{5}{|l|}{ cel: Transfer kolekcji do nowych magazynów } \\
\hline & Czynności & $\begin{array}{l}\text { Odpowiedzialny/ } \\
\text { /uczestnik }\end{array}$ & $\begin{array}{l}\text { Czas } \\
\text { trwania }\end{array}$ & $\begin{array}{l}\text { Środki } \\
\text { zasoby }\end{array}$ & Budżet \\
\hline & $\begin{array}{l}\text { 1. Stworzenie w łonie instytucji nowej koncepcji ochrony i udostęp- } \\
\text { niania kolekcji dekoracji teatralnych }\end{array}$ & $\cdots$ & $\cdots$ & $\ldots$ & $\ldots$ \\
\hline & 2. Stworzenie koncepcji magazynów dekoracji teatralnych & $\ldots$ & $\ldots$ & $\ldots$ & $\ldots$ \\
\hline & $\begin{array}{l}\text { 3. Określenie powierzchni i kubatury potrzebnych do przechowywa- } \\
\text { nia kolekcji dekoracji }\end{array}$ & $\ldots$ & $\cdots$ & $\cdots$ & $\ldots$ \\
\hline & 3. Wybór budynku zdolnego pomieścić kolekcję i jego adaptacja & $\ldots$ & $\ldots$ & $\ldots$ & $\ldots$ \\
\hline & $\begin{array}{l}\text { 4. Zaprojektowanie i wykonanie dostosowanego systemu przecho- } \\
\text { wywania }\end{array}$ & & & & \\
\hline & 5. Wykonanie kopii zestawów przeznaczonych do prezentacji w teatrze & $\ldots$ & $\ldots$ & $\ldots$ & $\ldots$ \\
\hline & $\begin{array}{l}\text { 6. Przeprowadzenie transferu kolekcji do nowego magazynu i jej in- } \\
\text { stalacja }\end{array}$ & & & & \\
\hline
\end{tabular}

Podczas tworzenia planu działania kluczowe jest ustalenie odpowiedniej i czytelnej sekwencji działań, jasne i precyzyjne określenie zadań i ich wykonawców, adekwatnie wykorzystujące kompetencje (co istotnie wpływa na motywację), szczegółowe i realistyczne określenie potrzebnych zasobów - zarówno ludzkich, jak i tych dotyczących czasu, potrzebnych przestrzeni, środków i narzędzi oraz finansów. Plan musi uwzględniać realia instytucji, której dotyczy - właściwości jej struktury, ramy działalności, codzienne funkcjonowanie, ewentualne trudności.

Rezultatem właściwie przeprowadzonego audytu konserwatorskiego jest zyskanie przez instytucję świadomości własnej sytuacji - niedociagnięć, ale 
i mocnych stron oraz potencjału, dzięki czemu jest możliwa racjonalizacja projektów i potrzeb. Wieńczący audyt plan działania, stworzony z uwzględnieniem powyższych istotnych warunków, powinien umocnić wolę zmiany, ułatwić podjęcie decyzji i stać się prawdziwym narzędziem transformacji prowadzących do wykreowania lepszej rzeczywistości danej instytucji sprawującej opiekę nad zbiorami stanowiącymi dobra kulturowe, a tym samym lepszych warunków ich trwania.

\section{Summary}

\section{Activities in the field of preventive conservation: audits of care - method and examples}

This article describes measures taken in the field of preventive conservation, known as audits of care, in the form in which they have been developed in the French school of preventive conservation since the 1990s. A brief outline is given of the types of evaluation which can be included in audits of care, beginning with the conservation assessment, moving on to the collections condition survey and the curatorial survey, and finally combinations of the above. It then describes the methodology and the way in which the assessment is conducted during audits of care and the way of presenting results and formulating action plans with the use of examples drawn from practice. 
A

1. Rozpoznanie i znajomość

zbiorów-inwentarz

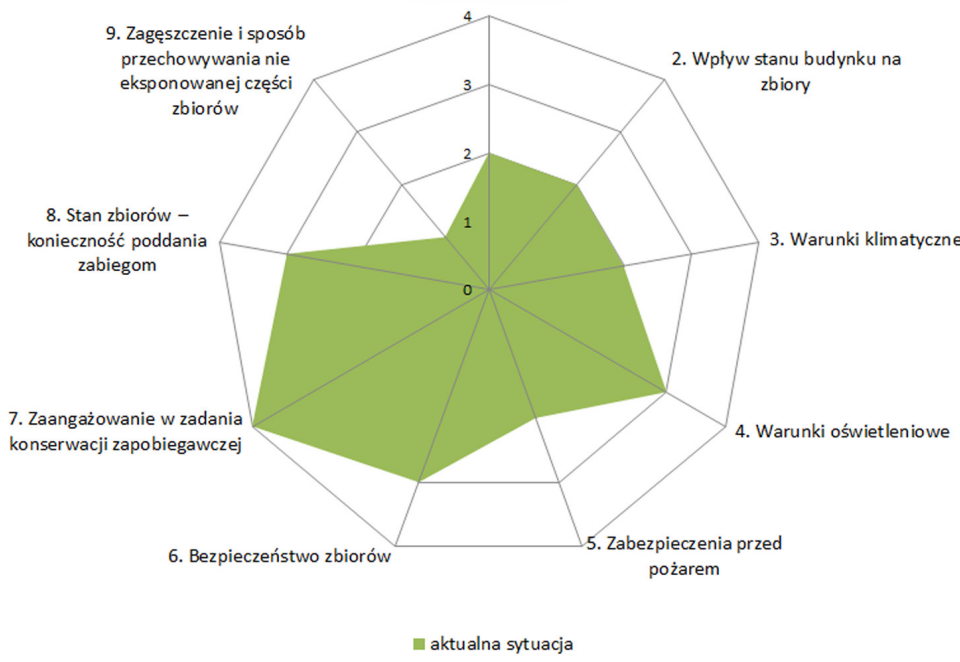

Il. 1. Graficzna prezentacja diagnozy w ramach audytu: przykład A. Autor: E. Szmit-Naud

B

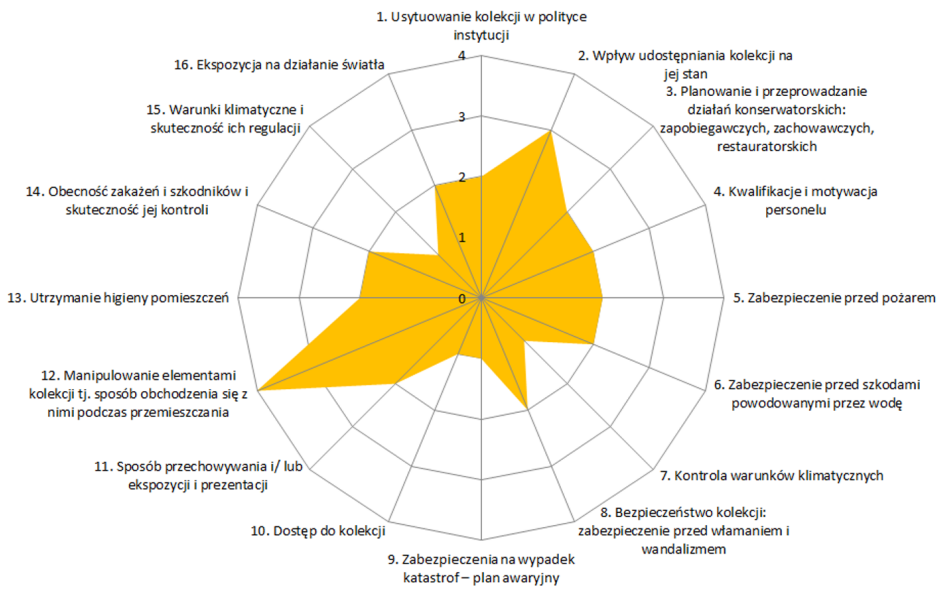

In sytuacja aktualna

Il. 2. Graficzna prezentacja diagnozy w ramach audytu: przykład B.

Autor: E. Szmit-Naud 